\title{
In this kind of situation, health as a public good once again becomes paramount..
}

Jeanette Vega MD PhD

Member, Global Preparedness Monitoring Board

Chief Medical and Innovation Officer, Red de Salud UC-Christus, Chile

Gail A. Reed MS

Dr Jeanette Vega is well known in global health circles for her work in the areas of health equity, social determinants of health and health systems. She has served as Chile's Vice Minister of Health, and as director of the country's National Health Fund (FONASA). For five years, she was also WHO Director of Equity and Social Determinants of Health. She currently sits on the 13-member Global Preparedness Monitoring Board (GPMB), co-chaired by H.E. Gro Harlem Brundtland, Former Prime Minister of Norway and Former WHO Director-General; and Mr Elhadj As Sy, Chair, Kofi Annan Foundation Board, and Former SecretaryGeneral, International Federation of Red Cross and Red Crescent Societies. An independent international monitoring and advocacy body, the GPMB prepared the seminal 2019 report on the state of global preparedness, A World at Risk.

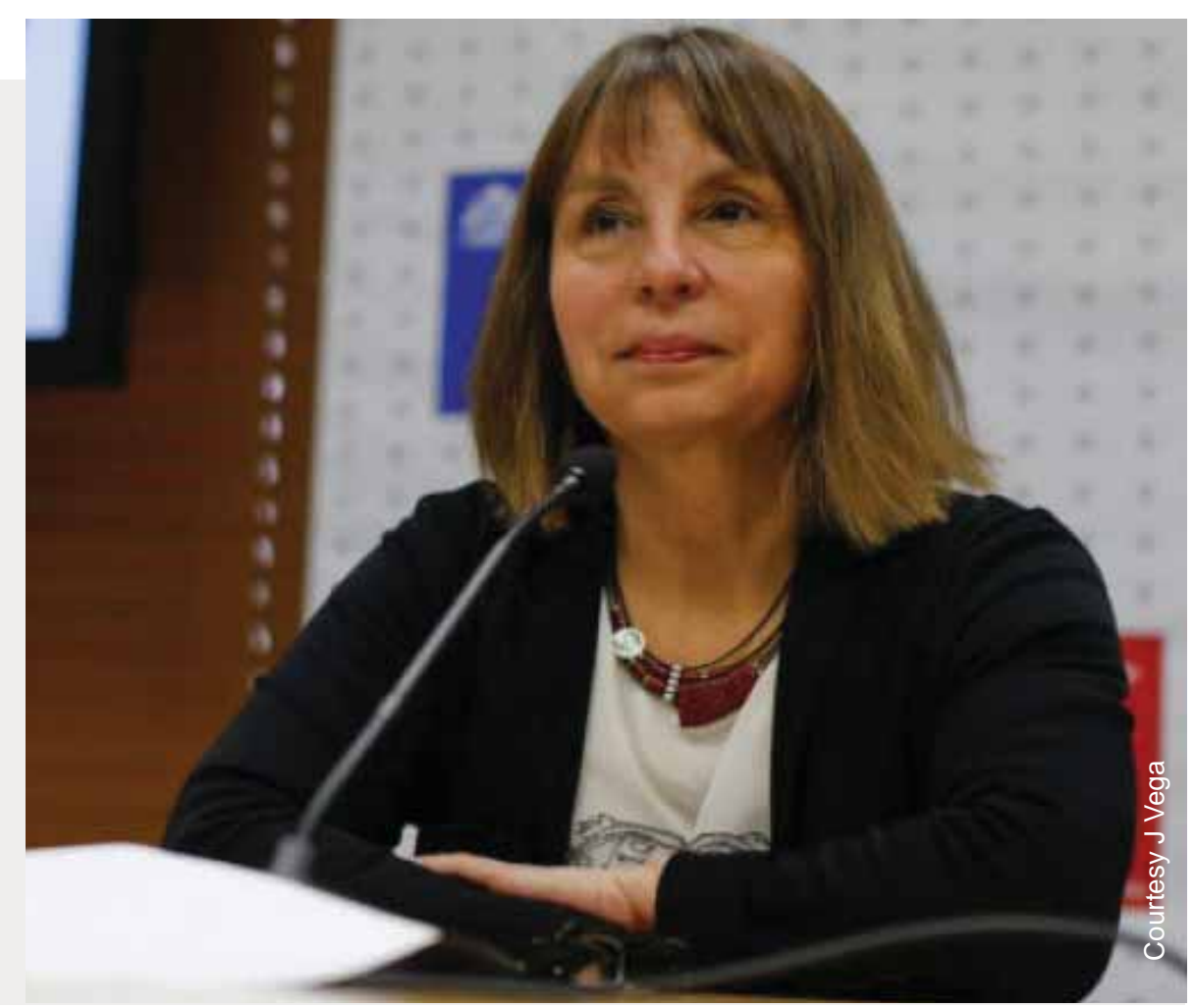

MEDICC Review: Unfortunately, A World at Risk was prescient in its warnings. Now that we are well into the COVID-19 pandemic, are there lessons we have learned...in addition to those we should have learned earlier?

Jeanette Vega: There are at least two types of lessons: structural and managerial. The structural ones are quite complex: despite our warnings and those of others about the disastrous consequences of a pandemic and the urgent need to boost resources dedicated to preparing for such a global emergency, this has not happened. Quite the contrary. Generally, public health systems remain fragmented with diminishing resources, especially in areas such as epidemic surveillance and control-areas that are invisible when they work well, but catastrophically visible when they don't. So I hope this is one big lesson we learn for the future: to be prepared for the worst, because if not, the social and economic consequences are brutal.

In terms of epidemic management, I think the biggest lesson is that nobody can save themselves by themselves. In this kind of situation, health as a public good once again becomes paramount: governments, provinces, states, cities and the people in them cannot act alone. This has been an extremely painful lesson for

those places where clear governance and well-defined strategies haven't been the rule.

\section{If you had to choose one global lesson from this pandemic, undoubtedly it would be that the neoliberal model touted around the world has failed}

Another painful lesson has to do with the importance of health itself: the terrible cost in human lives, especially for the poorest, but also in terms of the financial consequences leading us to a swift and brutal recession-and of course, once again, the countries most affected are our own, the poorer. So this points yet again to the need for organized and predominantly public health systems. If you had to choose one global lesson from this pandemic, undoubtedly it would be that the neoliberal model touted around the world has failed.

MEDICC Review: This brings up the implications for health systems in terms of universal coverage and access.

Jeanette Vega: Absolutely. Even in countries where the governing ideologies are quite conservative, such as France, they are suddenly rediscovering the role of what is public, the importance 
that prioritized economic resources and rights be held by all as public goods. So you see nationalizations happening in some of these countries, calling into question the privatizations that turned health care into a consumer item instead of a public good.

MEDICC Review: Does COVID-19 imply the need for changes in Chile's health system?

Jeanette Vega: Well, that's the hope, isn't it? But from what we've seen thus far, the government seems immune to what is happening, and its main priority is how to defend its economic power. At least until now, we don't see development of an economic growth model at the service of human well-being, or one that maintains health as paramount. Instead we see the emphasis on trying to minimize economic disruption...for example, the directive that people who don't go to work are liable to be fired, which goes against all principles of public health, and against all the measures of physical distancing and quarantine to stop viral spread. How can a person who is quarantined stay home when they know they will get fired?

MEDICC Review: So, is there a dichotomy between saving lives-taking care of health-and saving the national and global economies?

Jeanette Vega: No, this is a totally false dichotomy. The truth is that there is no economy without a workforce, and in order to go to work, people need to be healthy. It's as if we're returning to discussions of centuries past, which I thought had been laid to rest. Before it was capital vs. labor; now it is capital vs. healththe same thing, really. What's more, the goal of development for a planet, a country, has to do with social and personal well-being. Economic well-being is a tool for achieving that, a means but not an end in itself. The end is healthy people.

You see the divide between those who believe in democracy, in wealth distribution, in everyone having the same value, on the one hand, and those on the other hand who think that the most important thing is to maintain a healthy economy, which almost always translates into a healthy economy for the few who can reap the fruits of growth.

MEDICC Review: One of the recommendations in A World at Risk is related to the importance of a single, clear leadership in times of peril.

Jeanette Vega: Yes, we should make sure that we are guided by a single global leadership, and that is the World Health Organization (WHO). Yet, during the last few years, the very governments expected to give it most support have been undermining that leadership, creating instead parallel institutions. And when they do donate, these governments often earmark their funds for projects they are most interested in, which weakens WHO at a time like this. And I think this is a problem for the whole world, because we need a single voice that commands us all. Right now, we have WHO insisting on measures such as lockdown, isolation, contact tracing, testing and treatment. Yet, there are leaders of at least two major WHO contributors whose messages advocate just the opposite!

MEDICC Review: And within countries, does a single leadership play the same important role?
Jeanette Vega: Certainly. And this is a major problem. Because of social media, communication has become much more horizontal, which may be a good thing. But in these situations, it presents difficulties because there are actions needed that heed a single voice, as the result of a common discourse. When there is a health emergency, we need a central command, a single voice to which everyone is responsible. It's the only way. Imagine if you have 800 voices saying what they think should be done, giving instructions!

MEDICC Review: I recalled that you were first a family physician when I read the words of a doctor in Bergamo, northern Italy, who said: "This disaster could have been avoided with the massive deployment of health services at the community level..."

Jeanette Vega: Absolutely, yes, the role of primary health care! Look, even in countries like mine, the reason we've been able to maintain decent health indicators is because when the National Health Service was created, its main pillar was primary health care. Here in Chile, small planes and boats still make rounds in remote areas. And if it hadn't been for primary health care, despite so many years attempting to dismantle it, including during the Pinochet dictatorship, we wouldn't have the relatively good health indicators we have for a country with the size of our economy.

Primary care has to evolve,
reaching people at home
and where they work, with
new technologies

Primary health care is a fundamental strategy, and it's the main reason I'm now involved in innovation, because I think primary care itself has to evolve, reaching people at home and where they work, with new technologies. We need social innovation technologies, to return to a more humanistic medicine capable of reaching people where they are, with health professionals accompanying people in co-creating their health.

\section{MEDICC Review: A final word of advice?}

Jeanette Vega: We'll have to take a hard look at our deficiencies to come to a new understanding of what it means to be a healthy society. We're not going to make it out of this crisis if we don't begin to view the economy as a function of people, a function of the distribution of society's wealth. The coming recession is going to be very hard. We'll need a more Keynesian approach to maintain social cohesion until our populations recover, are able to reconstruct our societies' economies, and advance towards sustainable development...with equity. - $1 /$ w 